\title{
Resistance, a Facet of Post-colonialism in Women Characters of Khaled Hosseini's a Thousand Splendid Suns
}

\author{
Marzieh Gordan (Corresponding author) \\ School of Language Studies and Linguistics, University Kebangsaan Malaysia \\ Tel: $00601129081892 \quad$ E-mail: marzieh.gordan@yahoo.com \\ Areej Saad Almutairi \\ School of Language Studies and Linguistics, University Putra Malaysia \\ Tel: 0060122302350 E-mail: areej_almutairi@hotmail.com
}

Received: 06-02-2013

doi:10.7575/aiac.ijalel.v.2n.3p.240
Accepted: 08-04-2013

Published: 01-05-2013

URL: http://dx.doi.org/10.7575/aiac.ijalel.v.2n.3p.240

\begin{abstract}
This article looks at female level of resistance though the viewpoint of post-colonialism and feminism based on Khaled Hosseini's novel, Thousand Splendid Suns. The article concentrates on levels of resistance as a part of Afghan female's lifestyle against the gender oppression that are enforced on them through their lifestyle and culture, the objectives of their community and its standards. The novel is selected for the discussion of this problem as it shows the conflicts experienced by Afghan females in regards to their positions and roles in their community and to find a unique identification as an individual. Findings on the conflicts of females and the level of resistance factors are seen in the novel though the analysis of the two primary characters in the novel Maryam and Laila, as the reflection of the truth of Afghan female's lifestyle. The framework for the article is designed by using Stephen Selmon's, Edward Said's and Benita Parry's theories of level of resistance in the perspective of post-colonial and feminist literary discussion. This paper shows the observations created in regards to beliefs, gender discrimination and level of resistance within the area of Afghan female's lifestyle.
\end{abstract}

Keywords: female resistance, post-colonialism, feminism, identity, representation

\section{Introduction}

This research has drawn my attention and increased my understanding of the ways in which females deal with the demands of satisfying expectations of others, namely members of the family and community. This particular written text shows that in the perspective of Afghan womanhood, females experience conflicts when they try to fit into the public tasks and search for their personal identification at the same time. It also shows that Afghan females display a very simple yet resolute method of level of resistance that highlights the originality of Afghan feminity within their culture and community. By drawing back to their history and creative elements of their culture, Afghan females retell their tale of their situation, identities and desires of the eyes of Afghan woman's existence.

An Afghan-American author, Khaled Hosseini, was well-known as the 2006 Humanitarian of the Year by the U.S. office of the United Nations. A famous author who got his reputation, through his first novel The Kite Runner. A Thousand Splendid Suns, is its companion: a story of females, about affection and hatred, and resistance. A Thousand Splendid Suns guide us see the females under the burqas against the patriarchal male dominated society of Afghan.

The novel symbolizes problems of the struggle for liberalization at two levels, as post-colonial individuals and as females. In the post-colonial viewpoints, A Thousand Splendid Suns reveals conflicts of identifying and identification with regards to encounter in Afghan individual in the native lifestyle. While through the feminist viewpoint, the novel provides problems of struggle of Afghan females to find their own self-identity, revealed from the picture identified by patriarchal components and principles. The fundamental concern of the viewpoint is to notice the marginal position of post-colonial females in the societies that they live in.

The diagrams below report reflects citations to source items indexed within Web of Science. And it is about the women's resistance publications and number of citations that yearly have been done and cited, still continue by other authors from 2001 till today. But by increasing the number of citation we can say the topic that I have chosen for my article is a well-known area among the different writers till end of 2012 although it had a little decline in 2012. So issue of women and their struggle for empowering themselves always have been at the canter of attention as you can see below. 


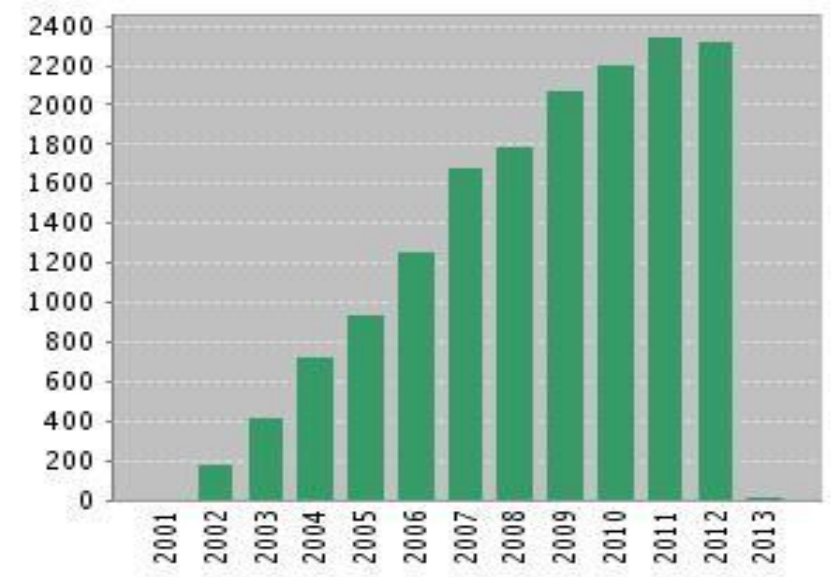

Citations in Each Year

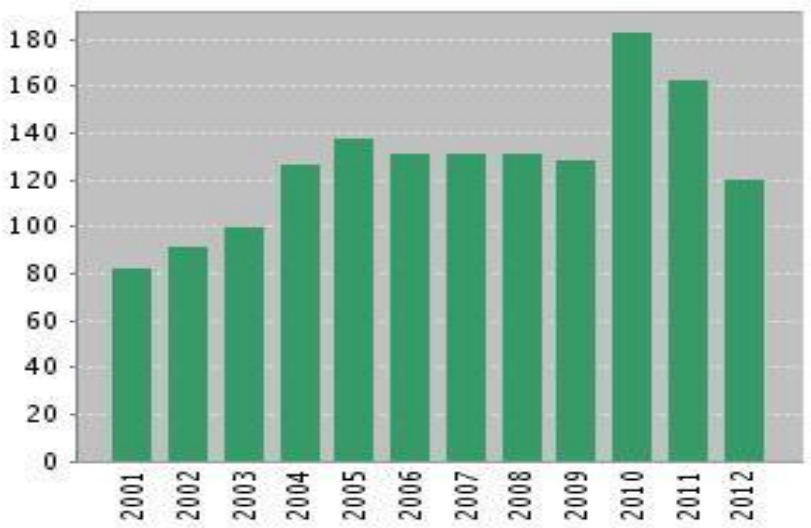

\section{Published Items in Each Year}

The theoretical framework of the idea of the level of resistance for this analysis is derived from experts such as BenitaParry (1997), Stephen Selmon (1997), and Edward Said (1993) Parry (1997:84-101) underline some of the methods of how level of resistance is indicated in literary works though her essay, 'Resistance Theory/Theorizing Resistance or Two Cheers for Nativism'. 'Unsettling the Empire: Resistance Theory for the Second World', Selmon (1997:72-83) focus on several explanations of literary level of resistance in post-colonial analysis. In the Parekh's content 'Redefining the post-colonial Females Self' (1996: 270-283), the idea of the level of resistance is provided in regards to the global perspective of post-colonial Afghan women.

The four women figures indicate the conflicts and problems of Afghan women across different classes of society. The novel focuses these problems though the actions, behavior, thoughts and awareness of Maryam, Nana, Laila and Fariba regard their role as women in their community and the problems they face in the course of their lives as Afghan women. Based on the level of resistance is determined when the figures decline or restore the positions and picture of Afghan women by not satisfying the objectives or superseding the standards of their lifestyle and community. The reflection of Afghan women as resisting women is determined through the types and forms of level of resistance represented by Maryam, Nana, Laila and Fariba in the novel. Although this article includes only the evaluation of the characters of the novel through the recognition of the element of level of resistance, it is important because the idea of the level of resistance is examined is in two viewpoints, post-colonialism and feminism.

There are two main objectives of this article. The first is to recognize the element level of resistance outlined or portrayed through characteristics, mind-set and changes of the female characters in the selected novel, Khaled Hossein's A Thousand Splendid Suns and to evaluate the element of level of resistance both in the viewpoint of post-coloniality and feminism in the viewpoint of Afghan females and their society which they live.

\section{Postcolonialism and Feminist Critical Studies: An Overview}

\subsection{Post-colonialism}

The main features of post-colonial studies in the world of literature next to the level of resistance consist of indignity, drawback and alienation, displacement and hybridity. Post-colonial research is self-discipline that is still changing and growing as it provides reasons for several questionable and controversial topics and problems. As Deepika Bahri (1996) states in her article "Coming to Terms with the "post-colonial", the area of post-colonial literary studies have been relevant to other crucial research such as feminism, postmodernism, deconstruction and post-structuralism. 


\subsection{Feminism}

Interpreting feminist writing is one of the popular projects of feminist critique. The meaning becomes difficult because of several factors. One of them is that the meaning varies according to the political ideology, social backdrop and the objective of works by different authors. The second purpose is that there seem to be many different genres of feminist criticisms that position different concentrates in each of the genres (Pam Morris : 1993). Because of these inconsistent roles within feminism itself, there appear several meanings according to the particular perspective and the main focus of the authors and critics in a particular work or categories of work of feminism.

Cheri Register (1975) in American Feminist Literary Criticism states that feminist literature must have served as a forum for women, contribute to gain cultural androgyny, supply role-models, encourage unity among women and raising awareness (1975:18-19). You can't just quote things, you need to apply them in the context of your discussion and expand critically. Also, this isn't a research proposal, it's an actual article so you should be more sophisticated in your subheadings.

\section{Postcoloniality and the Discourse of Resitance}

\subsection{The Basis of Postcolonial Resistance}

Level of resistance organizes the basic part of post-colonial writing. The published discourse supplies the contrivance and language becomes the procedure for indicating resistance towards the colonialist principles and development for the post-colonial authors. Zawiah Yahya's (1994) indictment estimated above factors the strong factors of the written discourse, particularly in literary works and academia. This supports the need for post-colonial authors to implement the discourse not only to "re-examine and resist the claims" (Zawiah Yahya 1994: 11) of the colonialist discourse but also to reproduce the authentic identification and carry ahead the world of the colonized individuals to the front.

Edward Said's idea of the post-colonial level of resistance is taken is one of his popular texts, Culture and Imperialism (1993). Going away from the extreme overall tone of the colonial level of resistance such as Fanon's opinions, Said (1993) indicates that the decolonization of social level of resistance does not plan to absolutely repudiate the colonizers element in the forming of new post-colonial identities. Alternatively, the level of resistance is determined by "intertwining histories" (Said 1993:259) of the colonizer and the colonized, linking the gap between the western societies and the native.

The connection between feminism and literature can be found mainly by means of substances and device. Feminism is the substance and the literary text become the product in which the material is designed and idealized to get the accurate reflection of the woman's world from a particular viewpoint. Level of resistance in feminist literature can be considered at two perspectives. The first in the challenging of the credibility of the male dominated or patriarchal literary tradition that misrepresents and undermines the women identification and encounters. The second resistance is considered in the renovation of new identities of women, which bring ahead the women discussion at the center of attention from the nonexistence or 'silenced' space of masculine discourse.

\section{Stephen Selmon's Definition of Resistance}

Selmon (1997) states that these groups often conflict with each other in the pedagogical area and literary practice. Illustrating from the last aspect, Selmon (1997) further clarifies the meaning and types of level of resistance that he has taken from critiques like Barbara Harlow, Selwyn Cudjoe, Jenny Sharpe, Gayatri Chakravorty Spivak, Homi Bhabha, Benita Parry and Jan Mohamed. By stating from Harlow (1987) and Cudjoe (1980), he creates the first level of meaning of resistance as, " an act or set of acts designed to release the people of its tyrants, and it so thoroughly introduces the experience of living under domination and pressure that it turns to be an almost autonomous principle" (Selmon 1997:77-78). This meaning is linked to this article as the element of level of resistance is portrayed through the connection of the oppressors and the masculine dominator and the oppresses as the female subject. The act of level of resistance is determined through the growth of the female characters in the novel as in the actions, behavior and ideas as their responses to the situation of being physically or mentally oppressed.

The second definition that Stephen Selmon (1997:78) derives from Gayatri Chakravorty Spivak, Homi Bhabha, and Benita Parry is as follows:

"A theory of literary resistance must recognize the inescapable partiality, the incompeleteness and the untrascendable ambiguity of literary or any contradiction or contestarory act which employ a Fist World medium for the figuration of the Third World resistance"(Selmon 1997:78).

Here the level of resistance is determined in regards to the dominant figure (the First World) through the recognition of the tendencies of the reflection and development of the Third World. In both explanations, literary level of resistance is underlined as a type of device or procedure to show the idea of staying away from accepting or producing to an imposition of developing positions or images by the dominant power. The major dominant figure of the First Globe in post-colonial concept is seen as a similarity of the patriarchal culture and principles in the Afghan community, as the representation of oppression of the women characters in A Thousand Splendid Suns.

\section{Benita Parry's Notion of Resistance}

In her theory 'Resistance Theory/Theorizing Resistance or Two Cheers for Nativism', Benita Parry (1997: 84-101) creates a structure of ways in which level of resistance is shown through the post-colonial viewpoint. One of her factors known as nativism however, is another important factor that utilizes reverse-discourse as a way to show the level of 
resistance. Reverse-discourse relates to the process of revealing the colonists structure of knowledge that considers to subjugate the colonized and therefore to change that framework, to suppress its domination and question its ethics (Parry 1997: 87). In this process, the existing form of the dominating discourse is restructured or reconstructed to achieve liberation through exposing the weaknesses of the discourse and superseding the negative oppressive values it carries.

The final aspect of resistance theory suggested by Parry (1997:88) is generated discourse, seen as the connecting aspect of both the post-colonial and feminist approaches. Gender discourse that focuses on gender issues in post-colonial experiences relate to the process of decolonization that debunks the western patriarchal assumptions of western/masculine and colonized/feminine structure. In this approach, the patriarchal assumptions are defined by reconstructing the female identity and bringing forward the issues of the female and femaleness as the fundamental element of post-colonialism. The analysis of the chosen novel primarily focuses on this aspect as the predominant part of the study to see the representation of Afghan women in their society.

\title{
6. The Role and Image of Afghan Women is the Thousand Splended Suns
}

In this level the discussion intends to emphasize the framework of the positions of Afghan females, concentrating on the idea of a wife hood on the traditional structure. The idea of wife hood here is seen as a way of life recommended for the married females that is identified within the factors regulating the guidelines and requirements of the Afghan community. In this specific novel, the group that attracts the beliefs is primarily that of Afghan lifestyle and culture, religious beliefs, with its concentration on the conventional framework. As described in many circumstances of Asian and Third Wold female's patriarchal social structure as described before the research will emphasize how the beliefs and positions of females in Afghan community is intensely affected and controlled by patriarchal thoughts. The discussion will illustrate that the patriarchal factor in the Afghan public framework often perpetuates females as the servants of men in almost all the positions that they perform.

It is also crucial that the pictures of Afghan females in the novel are mainly provided through the characters of young generation, namely Maryam and Laila. This features the point that pictures and beliefs of Afghan females mainly obtain from the traditional belief which dictated to the younger generation.One of the most prevalent pictures of the perfect Afghan wife in the Afghan community portrayed in the novel is the role as the slave to her husband and his family members. A good wife must belong to the belongings of her husband, who in all angels is considered to be her boss. He controls her with regards to her activities and even ideas. Preferably a wife must spend her whole life to satisfy her husband, and wish for the best things in his lifestyle for him.

Hosseini shows many particular components of the perfect features of females that are approved as the standard in the lifestyles of Afghan females. With the foundation that a lady must go through the pressure of discomfort, pleasure and go through the problems of life alone by controlling her feelings and needs instead of challenging or questioning them. Hosseini's choice to accomplish this compromise for her characters, the feedback of his anger depicts him as the picture and a reflection of a perfect feminist author.

\begin{abstract}
"There is only one, only one skill a woman like you and me needs in life, and they don't teach it in school . . . Only one skill. And it's this: tahamul. Endure . . . It's our lot in life, Mariam. Women like us. We endure. It's all we have. Do you understand? Besides, they'll laugh at you in school. They will. They'll call you harami. They'll say the most terrible things about you. I won't have it. . . There is nothing out there for her. Nothing but rejection and heartache. I know, akhund sahib. I know." (pp. 17-18; Here is the reality of life of Afghan females that Nana highlights early in the novel.)
\end{abstract}

The popularity of this declaration is seen the point that Hosseini becomes representational, it means that his characters are the representation of all individuals who are living in the same situation around the world, a famous legendary figure in the Afghan society that accept the success of a lady for her sacrifice. It shows how the framework of knowledge of the dominator, the patriarchal lifestyle is designed within the culture/religious area of Afghan community. This information is approved as the ethics of Afghan wife hood and approved as the perfect characteristics of dominating Afghan females.

The husband therefore reflects the figure of the authoritative master over his wife. The husband's significance in the conventional Afghan society is identifying female's identification is so excellent that without the prevalent determine of a man in the social life of a woman, she does not have an identification. The identification of a wife shown in the declaration is identified through the virtues of chastity, self-control and all the actions that she does in serving her spouse. Only then, the reliability of a woman will be honored. This is clearly portrayed through the female characters such as Maryam and Laila that fights after fights with their individual identities. These identities are gradually under management with the positions that they have to fit to as ideal wives to their husband. Despite the flaws of their husbands and sufferings that they have to go through, these females are always slightly impelled to spend for their husband's happiness and pleasure, not theirs.

This represents the role and situation of a wife as a simple reproduction device for her husband, besides being the slave for him and his close relatives, and therefore worthless if she is not able to carry out this role play. This shows the 
perception that the happiness and fulfillment for a perfect Afghan wife can be found in the happiness of her husband. Therefore, in the situation for Afghan females to get the perfect picture of wife hood, she must re-train her selfsatisfaction and personality so that she can provide herself to sacrifice her whole life for her husband, his needs and pleasure.

\section{Afghan Women Characters in The Thousand Splendid Suns}

In A Thousand Splendid Suns, Mr. Hosseini makes it obvious that he is engaged with the circumstances of females in Afghan society -- in the beginning, Nana speaks remarkably about "our lot in life," the lot of the inadequate, ignorant "women like us" who have to withstand the problems of life, the ignorance and suppression of men, the contempt of the community.

The young Mariam - the unlawful little girl of a rich person, a man who is embarrassed of her lifestyle - is easily marries her to a thirty-five years old shoemaker known as Rasheed, a piggy incredible of a man who says it annoys him "to see a man who's lost control of his wife". Rasheed makes Mariam to put on a burqa and disrespect her, make fun of her, abuses, even, "walking past her like she was nothing but a house cat." Mariam lifestyles in worry of "his shifting moods, his volatile temperament, his insistence on steering even mundane exchanges down a confrontational path that, on occasion, he would resolve with punches, slaps, kicks, and sometimes try to make amends for with polluted apologies and sometimes not."

It is through the sub-text of silence that Mariam tells the story of her grief and pain. Simone de Beauvoir in her book 'The Second Sex' notices: "A man performs chastity upon a woman" but on the other hand for himself performs and demand pleasure .

"There is a double demand which condemns woman to duplicity; he wants the woman to be his and to remain foreign to him. He fancies her as at once a servant, an enchantress but in public he admits only the first of these desires, the other is a demand which he conceals in the secrecy of his own heart and flesh" (221).

The life of the novel's other main character, Laila, who turns to be Rasheed's second wife, requires clearer velocity toward ruin. Though Laila is the valued little girl of an intellectual and modern man, who motivates her to engage in knowledge and learning, Laila discovers her lifestyle basically destroyed when a bomb - lobbed by one of the warlord groups battling for control of Kabul, and destroys her mother and father.

In the beginning Mariam recognizes Laila as a competing and blames her for taking Rasheed, her husband, but when Laila's child, Aziza, comes, Mariam starts to ease. Progressively, both of them become companions, attempt protect themselves from Rasheed's angers and orders. Mariam turns to be a second mother to Aziza, and both of them becomes best friends ever.

A generation born apart and with very different concepts about love, affection and family, Mariam and Laila are two females came together by war, misfortune and destiny. Both are poles apart in their disposition and conduct. We determine: "But, mostly, Mariam is in Laila's own heart, where she shines with the bursting radiance of a thousand suns" (402).

The analysis of each of these characters is by focusing on the idea of the level of resistance portrayed through the actions and thoughts of the characters. This is depending on the factors outlined in the conversation of the structure of this research. It notices that recognition of the level of resistance is seen in the action and thoughts that denies oppression through rebuilding or restricting the prescribed roles and image of women.

Maryam demonstrates the battles of the Afghan females who live in the conservative / Orthodox community and the knowledge she obtained from decades of sustained various sufferings as a woman. They indicate the females who are split between the conventional principles and discovering their personal feeling of self turned off from community and responsibility. We can look at their details as post-colonial as well as Afghan identity.

Maryam's rediscovery of her freedom is seen in the renovation of her part of a submissive wife and mother. This fits with Selmon and Parry's theory that shows levels of resistance through renovation of the picture of females. Here the renovation originates in what Parry has mentioned as a procedure as 'discourse-against' where the taken over determine "take up a position of separation" ( Parry 2997:88) from the dominant/universal topic. Chooses to subvert the recognized part portrayed by her religious beliefs, close relatives and community be recognizing the point that they have failed her. This is technically determined in Maryam's complete cutting off of the roles by leaving her town and fining a new self identification away from the expectation of her previous world.

Maryam's personality is portrayed in the earlier part of her life as a certified wife and little girl as who her close relatives and community has attracted through the picture of perfect women. In the early on about her wedding, Maryam highly considers that to it in the role of a true woman, she must carry herself as the slave, of her husband. She functions as tries her best to meet up with her roles with serious dedication and reliability to be able to achieve the perfect picture of a perfect Afghan woman and hence gain self-respect from her accomplishment. 
"Soon, Rasheed returns with a handful of pebbles and forces Mariam's mouth open and stuffs them in. He then orders her to chew the pebbles. In her fear, she does as he asks, breaking the molars in the back of her mouth. He tells her, "Now you know what your rice tastes like. Now you know what you've given me in this marriage. Bad food, and nothing else." (Pg. 94: This highlights that Mariam's inability to give Rasheed a son will continue to make him more and more bitter and unfriendly towards her.)

The women's self within the public and cultural values in which Maryam is showing gives no room for an individual personal identification. A female's identification is absolutely formed by the responsibilities and anticipations that was dictated to her by young age and not having to be able to create a personal feeling of self represents this.

Her husband's revenge on Maryam catches an important level of what is recognized as a failing in the chauvinistic, degrading perspective in the picture of Afghan womanhood. This is because the improbable objectives that are often set upon Afghan women once they have joined wedding become the most crucial factor that decides their reliability. Therefore a woman is not respected by her importance in the framework but rather in how much work, compromise and kids. The fact that the woman might experience and go through remarkable real and mental pain in accomplishing the improbable objectives enforced on them is not a phrase assessed in her benefits by the one-sided patriarchal idea of the culture.

Similarly Laila's decision to leave all the suffering behind, to build again a new sense of self, detached from her compulsion to fulfill others' expectations and needs marks one of the most significant female resistance in the novel. At this point Lalia realizes she has never achieved any happiness by building a sense of self predetermined by prejudices in her culture and society. Laila is portrayed as a woman she comes from a middle-class, well to do background. She represents the Afghan woman who belongs to the early times of the transition of traditional and modern values in Afghan culture and society. This marks one of the points that place Laila as the woman in-between. Another point, which is more significant in this portrayal of Laila as the woman in between being how she is drawn in terms of her attitude as principled as an Afghan woman towards her role as a wife.

In the same way Laila's choice to leave all the struggling behind, to develop again a new feeling of self, separated from her coercion to meet up with others' objectives and needs symbolizes one of the most important female resistance in the novel. At her point Lalia understands she has never obtained any pleasure by making a feeling of self pre-specified by prejudices in her life and community. Laila is represented as a woman who comes from a middle-class, well to do background. She symbolizes the Afghan woman who is connected to the beginning periods of the conversion of conventional and contemporary principles in the Afghan life and community. This symbolizes one of the factors that place Laila as the woman in between. Another factor, which is more important in this expression of Laila as the woman in between being how she is drawn with regards to her mindset as principled as an Afghan woman towards her role as a wife.

The restored feeling of self by illustrating the return to her natural attention and love for Laila represents the rebuilding of feeling of identification. By going back and recapturing the self that she was before she gets married, she shows the idea of opposite discussion in Parry's (1997) theory. Putting the Laila as the representation of discussion, the factors of level of resistance are shown in Maryam's act of remembering and changing the broken Laila, the feeling of self once fragmented and hidden behind the public tasks that she has to perform. This demonstrates the idea of reverse-discourse, by retracting the lost identity

Laila symbolizes the middle-class Afghan lady who has a perspective of her place and has more possibilities to discover life. Each level in her lifestyle shows certain essential aspects of her identification as an Afghan lady. Through the growth of her personality in these levels, the ideas of the mind and circumstances that result in conflicts, transgression from the standards and lastly level of resistance are captured in the novel.

The community of Afghan is frozen in a matrix of male domination and oppression wherein the inequality of the genders is both a heavenly require and a cultural construct. Hosseini gives a highly effective symbol of a patriarchal despotism where females are agonizingly reliant on fathers, husbands and sons. In this novel, one becomes aware of the role accepted to females by the community and the patriarchal society that is in conspiracy theory against the personality of the women individuals.

Women have no independence, are prohibited to work and are prohibited to travel without male chaperones to list only a few. They regularly become victims of male anger and misogyny. The marginalization of the woman's body is an evident truth. The gendered characteristics of assault have aggravated the nightmarish lifestyle. Its consequences are being introduced in the lifestyle in the form of domestic violence, cultural riots, enclosed areas and the policies of dislocation.

Females share experiences by their oppressions, jeopardizes, endurances, silences, and beaten down dreams and ambitions. Hosseini examines and probes into the encounter with strength, perfection and concreteness. The frequent design of misuse, wife battering and sexual assault are suggestions to the fact that the ladies are susceptible to marriage assault. A lady internalizes the man-made constructs even from beginning child years. She has no right to question and challenge. 


\section{Conclusion}

The first aspect of this analysis that talks about the image and roles of the Afghan wife centered from $A$ Thousand Splendid Suns notices how and where the position of females, particularly in the public aspect and the framework of a wife are drawn. Through the production in the novel, and further perspective into the characters of Maryam and Laila it is obvious that females are seen as second-class elements in the framework of conventional Afghan community.

The level of resistance therefore, become a component that involves ideas, activities, emotions and words as a result of doubting and declining to be captivated by the development of their identities by others, namely their community, family members, religious beliefs and objectives. Although each lady shows resistance in her own way, the very act of it, particularly the transgression that they present to the standards and objectives of their lifestyle represents the distributed and singularity that brings them together as resisting females.

The writing elucidates that level of resistance is a vital element of Afghan female's life as a method to find balance in their multitudinous tasks that they play is life. As seen in the research, there is a significant discontinuity between the public identification and the individual sense of self in the lives of Afghan females across background scenes and times. This discontinuity disputes due to withdrawal and frustration on the problems to get the beliefs enforced through the social roles. As a result, level of resistance occurred as a way to deal with the demands and constrains features through this written text that Afghan females illustrate their eccentricity through level of resistance towards the controlling components in their lifestyle that obtain from social roles, tendencies and prejudices in their lifestyle and community.

The character's stage of resistance is seen significally on the psychological stage throughout the growth of their personality in the novel. The expression of their characters signifies the possible interpretation of stage of resistance in the situation of former Afghan females that were still in a stage, controlled by conventional values, community and way of life.

\section{REFERENCES}

Beauvoir, S. d. (1949). The Second Sex. London: Vintage.

Gedalof, I. (1994).Against Purity: Rethinking Identity with Indian and Western Feminisms. London: Routledge.

Hosseini, K. (2007). A Thousand Splendid Suns. London: Bloomsbury.

Hosseini in Conversation with James Mustich, Editor-in-Chief, Barnes \& Noble Review .< http://www.barnesandnoble.com/bn-review/ note.asp?note>.

Nandy, A.F. (2003).Mapmaking: Partition Stories from 2 Bengals. New Delhi: Srishti Publishers.

Ashcroft, G. \& T. (eds). (1989. The Empire Writes Back. London: Routledge.

Bahri, D. (1996). Coming to Terms with the postcolonial . In Bahri, Deepika \& Vasudeva, Mary (eds). Between South Asian and Postcoloniality: The Lines, pp. 205-231. Philadelphia: Temple University Press.

Boehmer. E. (1995). Colonial and Postcolonial Literature. Oxford: Oxford University Press.

Desai, A. (1988). Voices in the City. New Delhi: Penguin Books.

Eagleton, M. (ed.). (1986). Feminist Literary Theory: A Reader. Oxford: Basil Blackwell Ltd.

Fannon, F. (1961). The Wretched of the Earth. London: Penguin Books.

Gandhi, L. (1998). Postcolonial Theory: A Critical Introduction. Australlia: Allen \& Unwin.

Hall, S. (1996). When was the postcolonial: Thinking at the Limit. In Chambers, I \& Curti (eds). The postcolonial Question, pp. 242-257. London: Routledge.

Katrak, K., H. (1995). Decolonizing Culture: Toward a Theory for Postcolonial Women's Text. In Parker, M \& Staykey R. (eds). pOstcolonial Literature, pp. 255-258. London: new Casebook macmillian.

Mann, H., S. (1995). Going in the Opposite Direction: Feminine Recunancy. In parker, M. and Starkey, R. (eds).

Anita Desai's Voices in the City in postcolonial Literature: Achebe, Nagugi, Desai and Walcott, pp. 73-83. London: Macmillian Press.

Maxwell, D.E.S. (1989). The Empire Writes Back. Ashcroft, Griffiths \& Tiffin (eds) London: Routledge.

Minh-Ha, T., T. (1995). Writing Postcoloniality and Feminism. In Parker, M. \& staykey R. (eds). Postcolonial Literature, pp. 264-268. London: New Casebook Macmiilian.

Mohanty, C., T. (1995). Under Western Eyes: Feminist Scholarship and Colonial Discourse. In Parker, M. \& Staykey R. (eds.). Postcolonial Literature, pp. 259-263. London: New Casebook Macmillan.

Morris, p. (1993). Literature and Feminism. Oxford: Blackwell Publishers Ltd.

Nasta, S. (ed.). (1991). Motherlands: Black Women’s Writing From Africa, the Caribbean and South Asia. England: The Women's Press.

Parekh, P., N. (1996). Redefining the Postcolonial Female Self: Women in Anitha Desai's Clear Light of the Day. In Bahri/ Deepika \& Vasudeva, Mary (eds). Between South Asian and Postcoloniality: The Lines, pp. 270-283. Philadelphia: Temple University Press. 
Parker, M., S., R. (eds.). (1995). Postcolonial Literature. London: New Casebook Macmillian.

Parry, B. (1997). Resitance Theory/Theorizing Resitance or Two Cheers for Nativism. In Mangia, Padmini (ed.). Contemporary Postcolonial Theory: A Reader,pp. 84-103 New Delhi: Oxford University Press.

Rajan S., R. (1993). Real and Imagined Women. London: Routledge.

Rushdie, S., \& West, E. (eds.). (1997). The Vintage Book of Indian Writing (1947-1997). London: Vintage Books.

Said, E. (1994). Culture and Imperalism. London: Vintage Books.

Schipper, M. (ed). (1985). Unheard Words: Women and Literature in Africa, The Arab World, Asia, the Caribbean and Latin America. London: Allison \& Busby.

Selmon, S. (1997). Unsettling the Empire: Resitance Theory for the Second World. In Mangia, Padmini (ed.). Contemporary Postcolonial Theory: A Reader, pp. 74-83. New Delhi: Oxford University Press.

Spivak, G.C. (1988). In Other Worlds: Essays in Cultural Politics. New York: Methuen.

Suleri, S. (1995). Postcolonial Literature. Parker, M. \& Staykey R. (ed.). London: New Casebook Macmillian. Walcott, D. (1972). In a Green Night. London: Jonathan Cape Ltd.

Zawiah Y. (1996). Resisting Colonialist Discourse. Bangi: Penerbit Universitu Kebangsaan Malaysia. 